\title{
Tumbuh dan Berkembang dalam Arsitektur
}

\author{
Faiz Widyastama dan Endy Yudho Prasetyo \\ Departemen Arsitektur, Fakultas Arsitektur, Desain dan Perencanaan, Institut Teknologi Sepuluh Nopember (ITS) \\ e-mail: endy_yudho_prasetyo@arch.its.ac.id
}

\begin{abstract}
Abstrak-Secara umum arsitektur merupakan sebuah wadah untuk menaungi berbagai aktivitas. Aktivitas tersebut dilakukan oleh pengguna yang berada di dalamnya, Akan tetapi beberapa pengguna didalamnya beranggapan bahwa arsitektur hanyalah sebuah benda mati yang tidak dapat berubah. Seiring berjalanya waktu penghuni yang berada didalamnya juga akan mengalami pertumbuhan dan perkembagan dan hal itu mempengaruhi kebutuhan aktivitas yang ingin diwadahi. Menanggapi hal tersebut fleksibilitas dalam arsitektur sangat penting karena dapat beradaptasi terhadap perubahan aktivitas yang dilakukan oleh pengguna. Fleksibilitas tersebut akan membuat anggapan bahwa arsitektur sebagai benda hidup yang dapat berubah mengikuti pertumbuhan dan perkembangan pengguna didalamnya.
\end{abstract}

Kata Kunci_Arsitektur, Aktivitas, Fleksibilitas.

\section{PENDAHULUAN}

$\mathrm{K}^{\circ}$ OTA merupakan pusat berbagai aktivitas ekonomi, perdagangan maupun pendidikan, sehingga memberikan konsekuensi bahwa sebagian besar kegiatan manusia berada di perkotaan. Penduduk yang melakukan perpindahan ke kota setiap tahunya terus meningkat, perpindahan itu sendiri dikategorikan menjadi dua macam, yakni migrasi penduduk dan mobilitas penduduk. Migrasi penduduk adalah perpindahan penduduk dari desa ke kota yang bertujuan untuk tinggal dan menetap di kota, sedangkan mobilitas penduduk berarti perpindahan penduduk yang hanya bersifat sementara saja atau tidak menetap. Arus migrasi ini berlangsung sebagai tanggapan terhadap adanya perbedaan pendapatan antara kota dan desa. Pandangan masyarakat mengenai kota adalah tempat untuk mencari rezeki sudah menjadi pola pikir dan kebiasan, sehingga tidak jarang jumlah masyarakat yang melakukan migrasi tiap tahunya terus bertambah.

Terbatasnya lahan permukiman diperkotaan membuat sebagian masyarakat membangun huniannya di tempat yang tidak diperuntukan untuk pemukiman. Akibatnya daerah yang mereka tempati akan menjadi lingkungan yang padat, hal ini lah yang menyebabkan kepadatan di kota. Jika tidak dikelola dengan baik maka kondisi seperti ini dapat menjadi penyebab terjadinya degradasi lingkungan, sehingga kualitas hidup masyarakat yang tinggal di daerah tersebut menjadi rendah. Lingkungan seperti ini berpotensi menimbulkan bencana, seperti kebarakaran dan banjir. Tidak jarang terjadi konflik penggusuran antara masyarakat dengan pemerintah. Penggusuran tersebut merupakan upaya untuk mengembalikan open space dan tanah milik pemerintah di perkotaan.

Kondisi pemukiman pada Jalan Joyoboyo dan Jalan Bumiharjo merupakan salah satu studi kasus pemukiman ilegal yang ada di Surabaya, Jawa Timur. Masyarakat yang tinggal didaerah tersebut menggunakan tanah pemerintah (PT

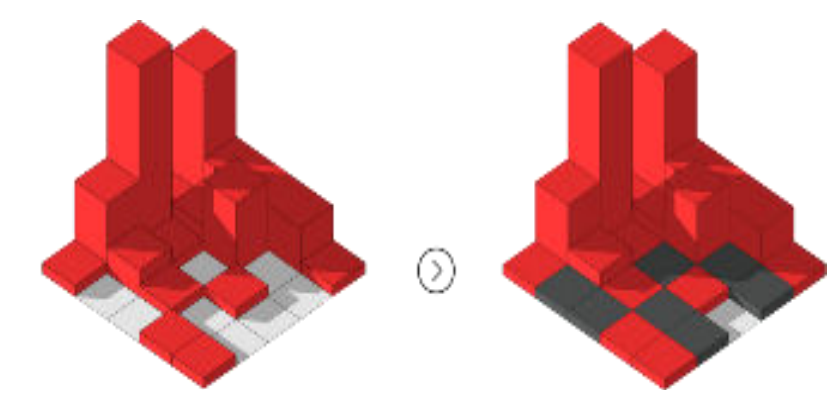

Gambar 1. Diagram perbandingan solid-void sebuah kota (kiri), Perbandingan solid-void setelah adanya pemukiman illegal (kanan).

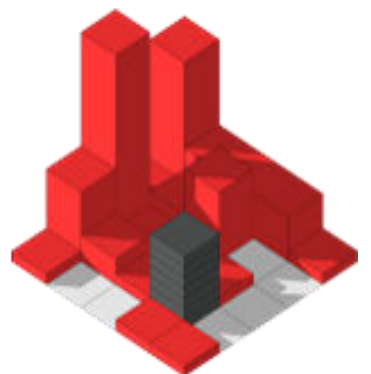

Gambar 2. Diagram perbandingan solid-void saat pemukiman illegal dikumpulkan kedalam satu massa.

KAI) sebagai lahan untuk membangun huniannya, masyarakat tersebut juga memanfaatkan fasilitas umum seperti stasiun yang sudah tidak beroperasi selama puluhan tahun sebagai tempat pemukiman. Pada saat yang bersamaan pemerintah Kota Surabaya memastikan proyek aktivasi kembali trem di Surabaya, Jawa Timur, mulai dilakukan tahun 2017 di jalur utara-selatan. Salah satu stasiun yang akan diaktifkan adalah stasiun yang berada dipemukiman Bumiharjo. hal ini menjadi persoalan bagi pemerintah kota Surabaya karena harus menggusur masyarakat yang berada di daerah tersebut.

Menanggapi permasalahan pemukiman ilegal pemerintah melakukan penertiban dengan merelokasi ke rumah susun, akan tetapi apakah ruang yang ada didalam unit rumah susun dapat beradaptasi terhadap perubahan aktivitas yang terjadi, karena seiring berjalanya waktu penghuni didalamnya akan tumbuh dan berkembang sehingga mempengaruhi kebutuhan aktivitasnya.

\section{METODA PERANCANGAN}

Fleksibilitas digunakan sebagai pendekatan karena memberikan gambaran yang berkaitan dengan kemudahan untuk berubah terhadap sesuatu, kemudahan untuk berubah ini terletak pada apa yang dilihat sebagai sesuatu yang mengikuti perkembangan waktu. Fleksibilitas dalam arsitektur merupakan sebuah konsep lama yang dikenalkan sebagai antimodernisme, konsep ini dapat dikembangkan kembali dalam 

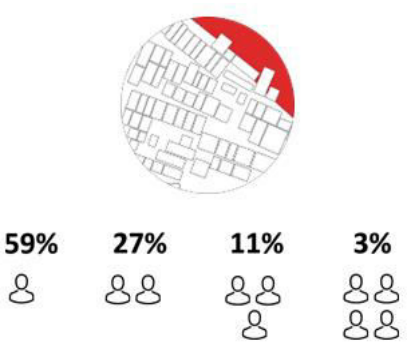

Gambar 3. Persentase jumlah anggota keluarga Kp. Bumiharjo.
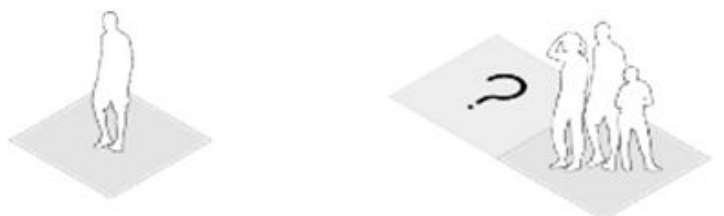

Gambar 4. Diagram tidak adanya fleksibilitas ruang dalam arsitektur.
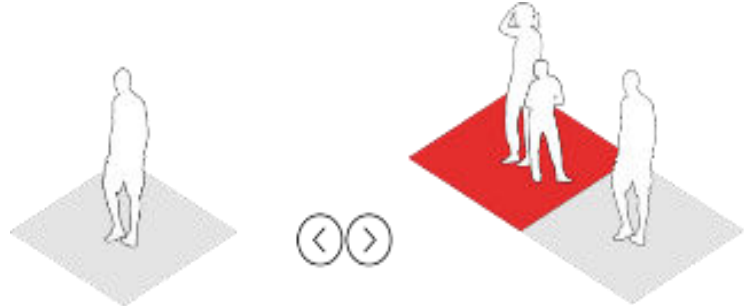

Gambar 5. Diagram adanya fleksibilitas ruang dalam arsitektur.

perancangan hunian bagi masyarakat berpenghasilan rendah. Seperti yang dikatakan Kronenburg bahwa fleksibel dalam bangunan dimaksudkan untuk menanggapi perubahan dan bereaksi pada bentukan bangunan itu sendiri, beradaptasi dengan perubahan yang baru, sehingga arsitektur nantinya tidak dianggap sebagai benda yang statis, melainkan dapat tumbuh dan berkembang. Dalam tulisannya Dimensi Ruang dan Waktu terdapat tiga konsep mengenai fleksibilitas, yaitu [1]:

\section{A. Ekspansibilitas (Expansibility)}

Merupakan kemampuan untuk berubah dari suatu keadaan awal menuju keadaan yang baru dalam waktu tertentu. Perubahan ini dapat mempengaruhi interior atau eksterior sebuah arsitektur, memungkinkan sebuah objek arsitektur memiliki kemampuan mengubah ruangnya dengan cara memperluas atau memodifikasinya sesuai kebutuhan yang ingin diwadahi

\section{B. Konvertibilitas (Convertibility)}

Perubahan suasana dan orientasi bangunan sesuai keinginan pengguna dalam jangka waktu kedepan tanpa harus mengubah secara keseluruhan.

\section{Versatilitas}

Ruang multifungsi yang dapat menampung berberapa aktivitas, melakukan berbagai aktivitas didalam satu ruangan yang sama.

Fleksibilitas yang digunakan dalam perancangan rumah susun ini berfokus bagaimana sebuah unit dalam rumah susun arsitektur dapat memperluas ruanganya (Expansibility).
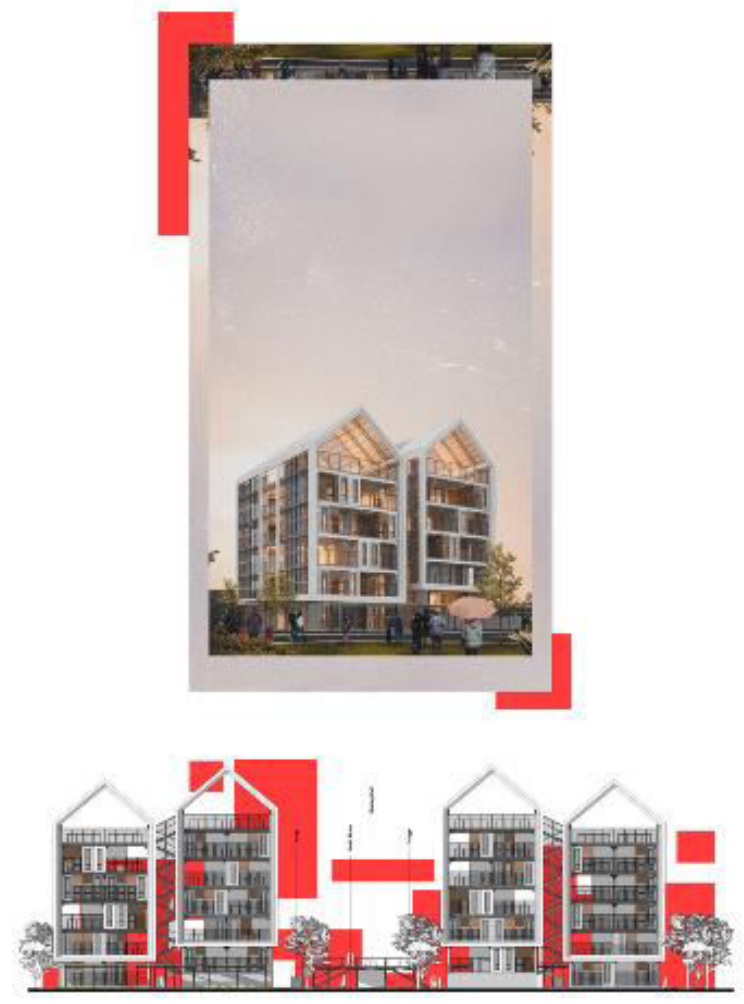

Gambar 6. Perspektif dan tampak depan.

Metode yang digunakan kedalam perancangan ini terbagi menjadi 3 kategori:

\section{Formal Tools}

Aspek formal yang akan ditawarkan adalah membuat hunian vertikal dan mencoba memasukan karakteristik dari sebuah kampung, dimana konfigurasi massanya memiliki susunan yang acak, sehingga Hal ini yang coba diterapkan kedalam perancangan. Dapat kita ketahui bahwa tatanan massa yang berantakan pada sebuah kampung terjadi secara alami, kita tidak dapat memprediksi berapa jumlah anggota keluarga pada tetangga kita dan seberapa luas hunian yang mereka dirikan. Akan tetapi kita dapat membuat seolah-olah hal itu terjadi jika kita mempunyai suatu pola tertentu.

Salah satu cara untuk membuat pola tersebut adalah menggunakan bilangan biner (binary number). Bilangan ini nantinya dapat dijadikan sebuah sistem penataan unit-unit yang berada didalam rumah susun. Nantinya bilangan biner ini dapat menentukan unit apa yang berada disampingnya dan apakah posisi unitnya mendapatkan halaman depan atau belakang. Penentuan posisi halaman pada unit rumah susun ini dapat memberikan opsi kepada pengguna karena beberapa pengguna ada yang menyukai halaman dibagian belakang dan beberapa lainya yang menyukai halaman di depan tergantung aktivitas yang ingin diwadahi.

Cara yang dilakukan untuk membuat kesan berantakan adalah melakukan transformasi kata "Architecture As Living Organism" menjadi bentuk bilangan biner, Bilangan biner ini nantinya dapat disesuaikan dengan kode yang terdapat pada masing-masing tipe unit hunianya dan dapat digunakan sebagai pola dalam menyusun form pada bangunan. 

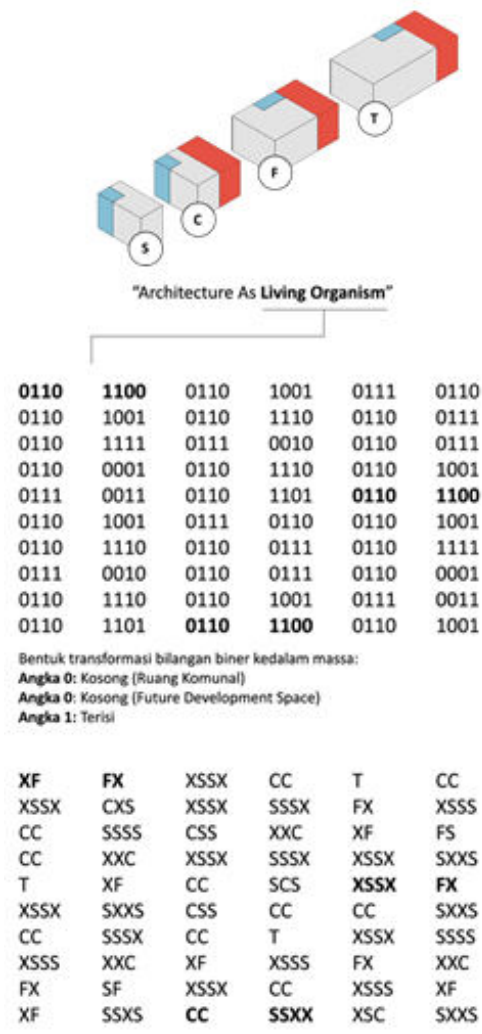

S: 85 unit $C: 46$ unit F: 18 unit $\mathrm{T}: 5$ unit (Total: 156 unit) $x$ : Ruang Komunat Dengan parameter persentase warga yang berada di RW 05 Bumihario
5: 59\% C: 27\% F: $11 \%$ T: $3 \%$

"Architecture As Living Organism"

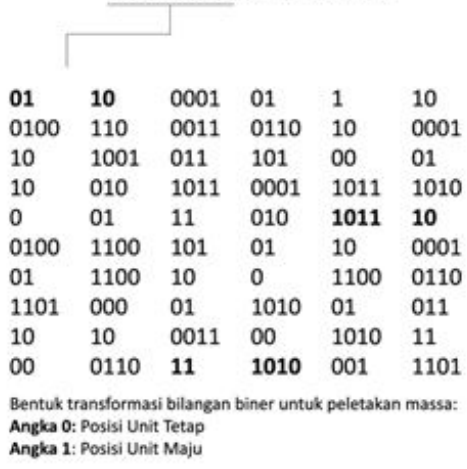

Gambar 7. Diagram transformasi bilangan biner.

Sebelum masuk kedalam proses transformasi kedalam bilangan biner, perlu diketahui sebelumnya terdapat 4 tipe unit hunian, masing-masing unit huniannya memiliki kode biner

1. Tipe $\mathrm{S} 18 \mathrm{~m}^{2}-($ No Expansion) Kode Biner: 1

2. Tipe C $18 \mathrm{~m}^{2}-36 \mathrm{~m}^{2}$ (After Expansion) Kode Biner: 01/10

3. Tipe $\mathrm{F} 36 \mathrm{~m}^{2}-54 \mathrm{~m}^{2}$ (After Expansion)

Kode Biner: 110/001

4. Tipe T $54 \mathrm{~m}^{2}-72 \mathrm{~m}^{2}$ (After Expansion)

Kode Biner: 1110/0111

Angka 0: Kosong (Future Development Space)

Angka 1: Terisi

Future development space merupakan ruang kosong yang dapat digunakan untuk melakukan ekspansi. Dalam proses transformasi kedalam bentuk bilangan biner terdapat beberapa
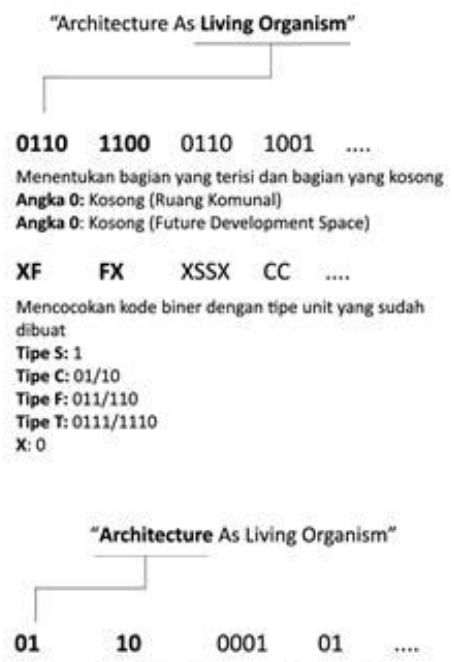

Menentukan posisi maju atau mundur unit hunianya Angka 0: Posisi Unit Tetap - Angka 1: Posisi Unit Maju

Posisi maju atau mundur berguna agar semua unit pada rumah susun mempunyai opsi apakah mereka ingin halaman yang berada didepan atau belakang
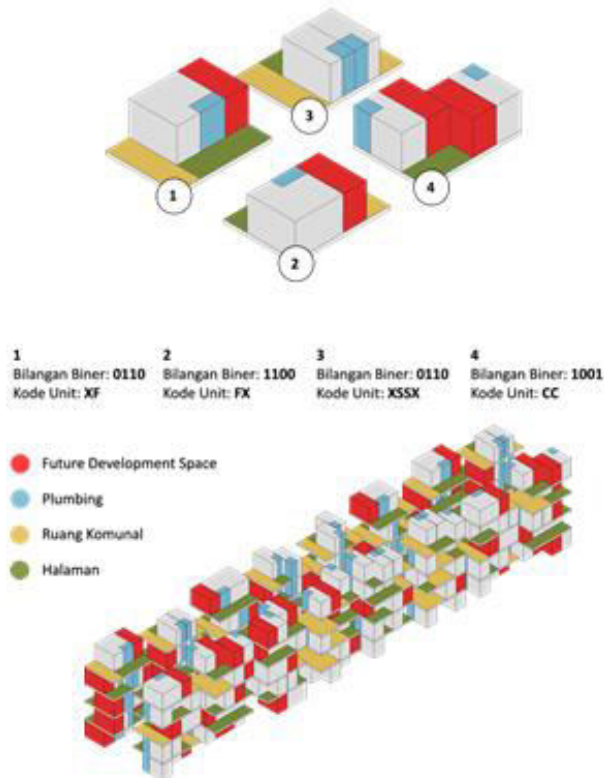

Gambar 8. Cara membaca pola bilagan biner dan diagram susunan massa keseluruhan.

ruang kosong (disimbokan dengan huruf $\mathrm{X}$ ), kemudian ruang ini yang dapat dijadikan sebagai ruang komunal.

Ketika ada unit yang mendapatkan Future Development Space dan terdapat ruang komunal disampingnya, maka selain menggunakan future development space untuk ekspansi, maka unit tersebut akan mempunyai opsi untuk ekspansi menggunakan ruang komunal disampingnya, sehingga ekspansinya menjadi tiga kali lipat. Ekspansi menggunakan ruang komunal $(\mathrm{X})$ akan dikenakan biaya tambahan, contoh: Tahap 1: Tipe C $18 \mathrm{~m}^{2}$

Tahap 2: $36 \mathrm{~m}^{2}$ (Ekspansi dengan Future Development Space) Tahap 3: $54 \mathrm{~m}^{2}$ (Ruang komunal (X) sebagai ekspansi tambahan) 

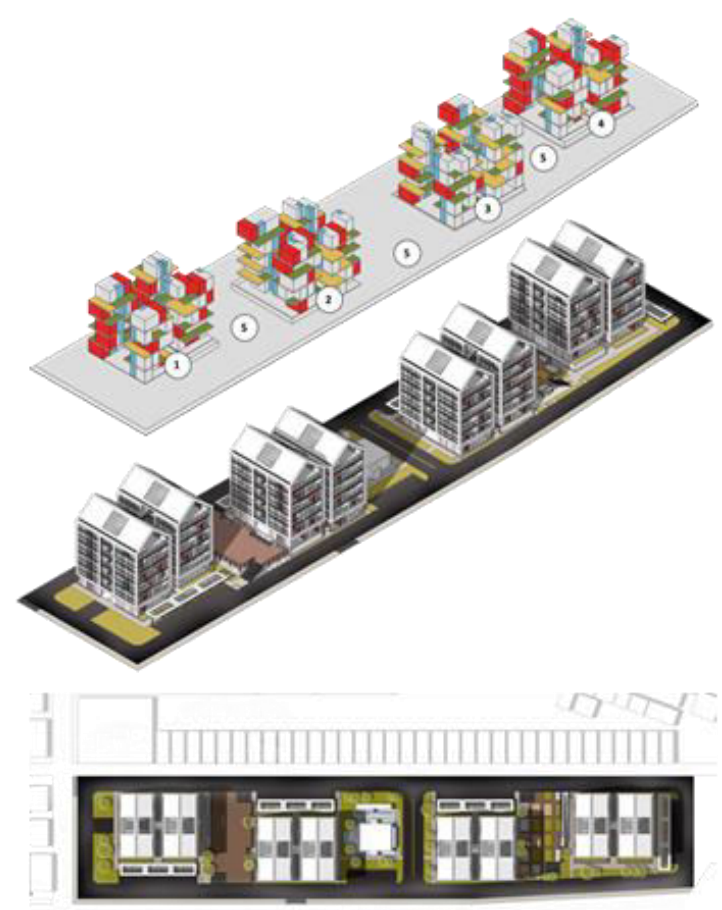

Gambar 9. Cara membaca pola bilagan biner dan diagram susunan massa keseluruhan.

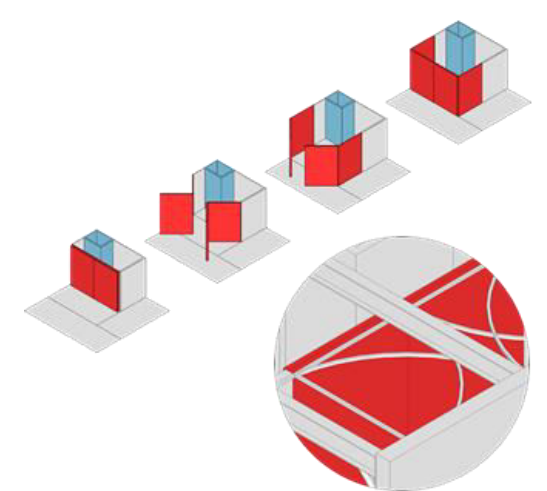

Gambar 10. Cara kerja folded wall pada future development space.

\section{E. Conceptual Tools}

Merupakan aspek yang berkaitan dengan ide atau gagasan utama yang akan diangkat. Ide atau gagasan ini nantinya akan menjadi sebuah konsep untuk menyelesaikan masalah. Dalam kasus ini permasalahan yang terjadi berkaitan dengan ruang. bagaimana arsitektur dapat dianggap sebagai benda yang hidup, benda yang dapat tumbuh dan berkembang. Cara yang di lakukan adalah menggunakan teori intagible metaphors, sebuah bentuk pengandaian yang berasal dari sesuatu yang tidak bisa di raba (conceptual), dalam hal ini perancangan arsitektur mencoba menganalogikan arsitektur sebagai makhluk hidup yang mempunyai karakteristik tumbuh dan berkembang [2].

Pertumbuhan dan perkembangan dalam rumah susun ini dapat diperhatikan dengan cara melihat apakah Future Development Space dan ruang komunal (X) sudah digunakan untuk melakukan ekspansi atau belum. Secara umum akan terlihat jika suatu benda mengalami pertambahan volume, maka benda tersebut mengalami pertumbuhan dan

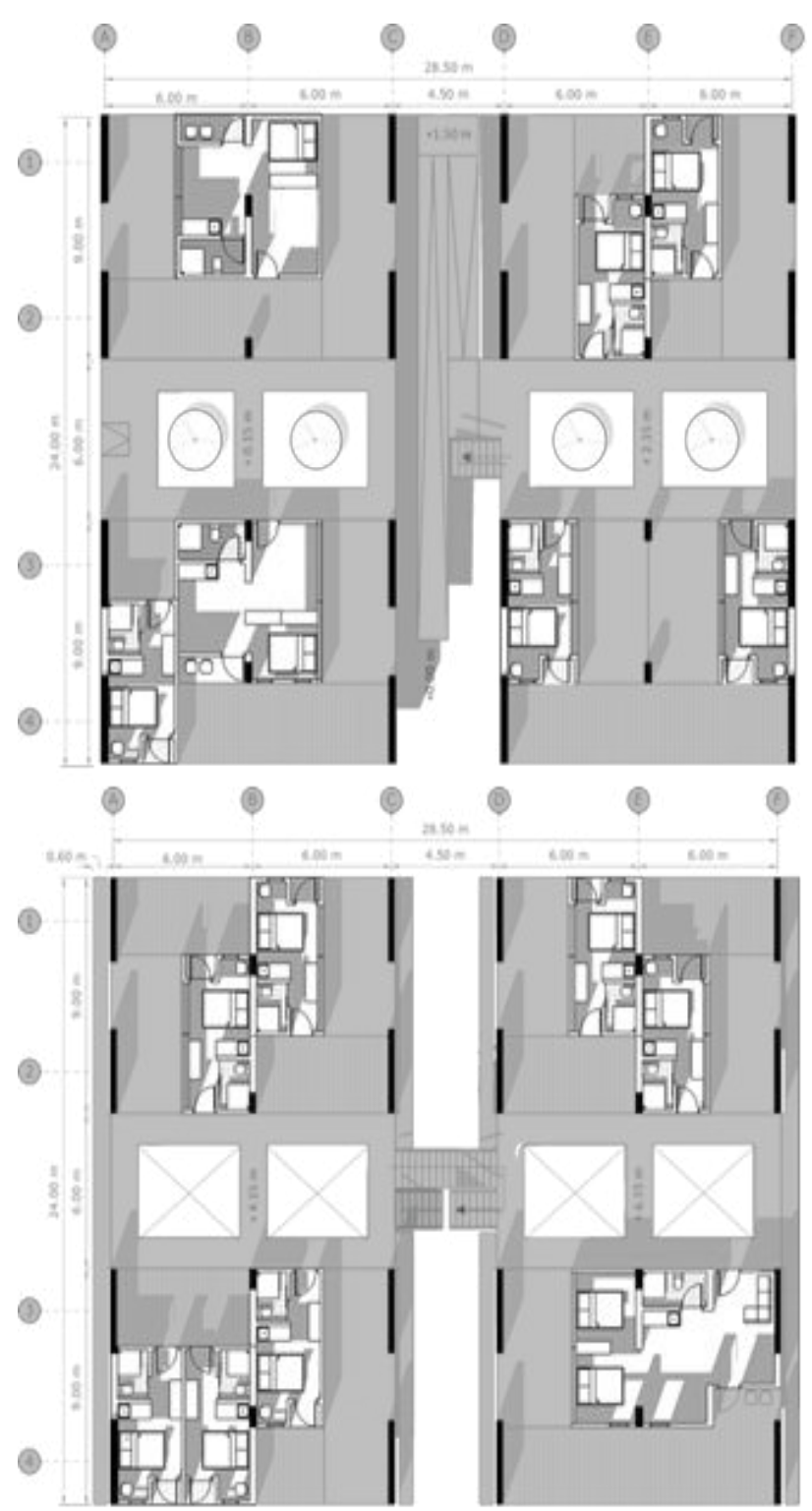

Gambar 11. Contoh tatanan unit massa pada denah.

perkembangan, pandangan seperti yang coba diterapkan kedalam sebuah arsitektur.

\section{F. Programmatic Tools}

Untuk mendukung conceptual tools agar arsitekturnya dapat melakukan proses tumbuh dan berkembang secara teknis, metode yang digunakan adalah metodologi housing as a verb, perumahan bukanlah unit statis yang di kemas dan diserahkan kepada orang-orang [3], sebaliknya, sebuah perumahan harus dipahami sebagai proyek yang sedang berlangsung dimana penghuni juga berperan sebagai co-creators huniannya. Metodologi Housing as a Verb inilah yang digunakan dalam perancangan hunian yang fleksibel, dimana pengguna hunian dapat memodifikasi dan mengisi ruanganya sesuai kebutuhan yang ingin diwadahi. Jika dimasukan kedalam konteks rumah susun, metode ini berguna ketika penghuni yang berada di unit huniannya mengalami perkembangan, perkembangan ini merupakan bertambahnya individu yang menempati satu unit hunian atau bertambahnya aktivitas yang ingin diwadahi. 
Secara tidak langsung hal tersebut membutuhkan penghuni untuk berpartisipasi menghadirkan ruang yang lebih, kemudian unit hunian dalam perancangan ini memungkinkan ruang yang ada dapat di tambah maupun dikurangi. Secara keseluruhan dapat dilihat bahwa arsitekturnya menjadi sangat fleksibel karena dapat ditambah maupun dikurangi.

\section{HASIL DAN EKSPLORASI}

\section{A. Konsep Zonasi}

Tatanan massa bangunan terdiri dari 4 blok, masing-masing blok memiliki 2 massa yang saling terhubung, kemudian ke 4 blok tersebut disusun menggunakan konsep "checkerboard", dimana diantara bloknya terdapat fasilitas publik seperti taman, parkir motor dan masjid, Tatanan blok tersebut bertujuan agar semua massanya mendapatkan keindahan landscape. Pada bagian depan masing-masing blok terdapat tempat parkir mobil, sedangkan untuk parkir motor, kantor pengelola, ruang pompa dan ruang elektrikal berada di bawah taman (floating park).

Pada siteplan terdapat sirkulasi yang mengelilingi area bangunan yang bertujunan memudahkan aksesibilitas bagi pemadam kebakaran untuk mengakses titik hydrant serta servis lainya seperti loading dock untuk sampah.

Berikut pembagian zonasi pada area tapak:

1. Blok A

2. Blok B

3. Blok C

4. Blok D

5. Fasilitas Umum (Parkir, Taman dan Masjid)

\section{B. Konsep Unit Hunian}

Fitur future development space merupakan cara untuk menciptakan arsitektur yang fleksibel, dimana arsitekturnya dapat dimodifikasi sesuai dengan kebutuhan pengguna. Dalam konteks ini objek yang dirancang adalah rumah susun dengan sistem sewa, maka setelah unitnya dapat melakukan ekspansi, unit tersebut harus dapat dikembalikan seperti semula, sehingga unitnya dapat disewakan kembali kepada penghuni yang baru.

Untuk itu teknis penambahan ruang pada Future Development Space adalah menggunakan dinding lipat (folded wall). Dinding partisi ini terdiri dari beberapa lapis, tebal satu dinding sebesar $80 \mathrm{~mm}$ dengan material GRC Board, besi Hollow dan busa untuk meredam suara yang masuk. Dinding tersebut dikaitkan pada sebuah rel dibawah balok yang memberikan kemudahan bagi penghuni untuk menggeser dinding sehingga volume ruang pada unit huniannya dapat ditambah maupun dikurangi (fleksibel). Adanya fitur ini dapat mendukung ide bagaimana arsitektur dianggap sebagai benda yang hidup, benda yang dapat tumbuh dan berkembang.

Unit huniannya disusun berdasarkan bilangan biner maka pada setiap lantai dan massanya memiliki konfigurasi yang berbeda-beda, hal ini yang coba diterapkan agak kesan berantakan pada sebuah kampung masih tetap ada ketika dipindah kedalam hunian vertikal.

\section{KESIMPULAN}

Seiring berjalanya waktu aktivitas akan mengalami perubahan, perubahan ini dapat berpengaruh terhadap arsitekturnya, Jika di masa yang akan datang arsitekturnya tidak mampu mewadahi perubahan aktivitas yang terjadi, maka pengguna di dalamnya hanya akan beranggapan bahwa arsitektur hanyalah sebuah benda statis yang tidak dapat berubah. Fleksibilitas terhadap ruang ditawarkan sebagai alternatif desain didalam rumah susun, ketika penghuni didalamnya mengalami proses perkembangan dan membutuhkan space lebih, maka space didalamnya dapat ditambah maupun dikurangi sesuai aktivitas yang ingin diwadahi. Secara tidak langsung ketika sebuah benda dapat bertambah volumenya, maka benda tersebut melakukan proses tumbuh dan berkembang. Hal inilah yang coba diterapkan kedalam desain agar arsitektur tidak hanya dianggap sebagai benda yang statis, melainkan arsitektur dianggap sebagai hidup, benda yang dapat tumbuh dan berkembang sepertihalnya manusia.

\section{DAFTAR PUSTAKA}

[1] Toekio, Dimensi Ruang dan Waktu. Bandung: Intermatra, 2000.

[2] A. C. Antoniades, Poethic of Architecture. New York: Van Nostrand Reinhold, 1990.

[3] J. F. C. Turner, "Freedom to Build," New York, 1972. 